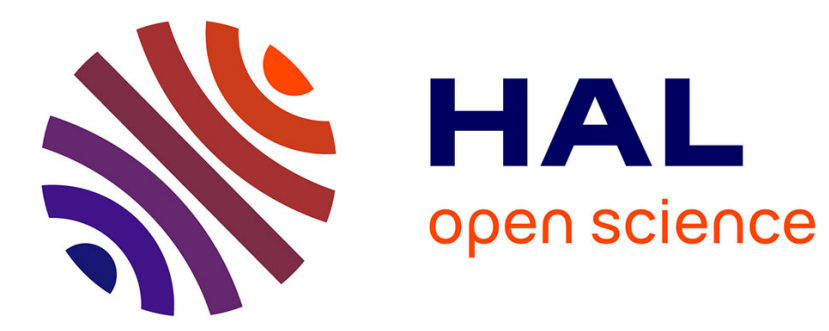

\title{
A historiographical overview of the current state of research into Jean Le Rond D'Alembert (1717-1783)
}

Alexandre Guilbaud, Christophe Schmit

\section{To cite this version:}

Alexandre Guilbaud, Christophe Schmit. A historiographical overview of the current state of research into Jean Le Rond D'Alembert (1717-1783). Centaurus, 2017, 59 (4), pp.251-262. 10.1111/16000498.12168 . hal-02904827

\section{HAL Id: hal-02904827 \\ https://hal.science/hal-02904827}

Submitted on 22 Jul 2020

HAL is a multi-disciplinary open access archive for the deposit and dissemination of scientific research documents, whether they are published or not. The documents may come from teaching and research institutions in France or abroad, or from public or private research centers.
L'archive ouverte pluridisciplinaire HAL, est destinée au dépôt et à la diffusion de documents scientifiques de niveau recherche, publiés ou non, émanant des établissements d'enseignement et de recherche français ou étrangers, des laboratoires publics ou privés. 


\section{A historiographical overview of the current state of research into Jean Le Rond D'Alembert (1717-1783)}

Alexandre Guilbaud, Christophe Schmit, "A historiographical overview of the current state of research into Jean Le Rond D'Alembert (1717-1783)”. Centaurus, 2017, 59 (4), pp.251-262.

This year we are celebrating the tercentenary of the birth of Jean Le Rond D'Alembert, a multi-faceted figure whose image and legacy have been reassessed in recent research publications. A member of both the French Royal Academy of Sciences (he was admitted in 1741 in the quality of "adjoint astronome") and the French Academy of which he became permanent secretary from 1772, D'Alembert was a foundling, a mathematician who made fundamental contributions to pure and mixed mathematics (astronomy, optics, mechanics, etc.), the co-editor with Diderot of their Encyclopédie, a philosopher, a writer, a translator, who enjoyed privileged correspondence with Lagrange, Voltaire and Frederic II of Prussia. He was, in short, a man fully engaged in the debates of his time.

Despite the pivotal role D'Alembert played in the Enlightenment period, the project to establish a critical, fully annotated edition of his collective works only began to take shape at the end of the twentieth century. Previous editions which collected his writings, such as those by C. Pougens (D'Alembert, 1799), J.-F. Bastien (D'Alembert, 1805) and A. Belin (D'Alembert, 1821-22), or even C. Henry (1887), were quickly available, from the end of the 18th century onwards, but all, without exception, were incomplete. In particular, they excluded from publication his scientific texts, whether it be a treatise (of which, at best, they included the preface) or a memoir, and the entries he wrote in the Encyclopédie dealing with mathematics and physics, as if finally the 19th century only retained the literary dimension of his work. None of these editions contains, besides, any justification for the choice of the texts selected, or historical perspective or even any explanatory notes which could help to clarify a difficult passage, the context or what was at stake. The turning point came with G. Maheu's remarkable biographical and bibliographical doctoral thesis (1967) under the tutorship of R. Taton and J. Pappas' inventory of the correspondence $(1986 ; 1989)^{1}$; thus could begin the long and indispensable process of itemizing all of D'Alembert's works.

These are the founding stones on which a cross-disciplinary team of researchers ${ }^{2}$ has been building since the beginning of the 1990s to establish a critical and annotated edition of the collected works (Euvres complètes) of D'Alembert. A long preliminary phase consisted, among other activities, in making a list of all published material ${ }^{3}$, itemizing the manuscripts and correspondence, establishing precise timelines and sifting through the press of the period. Out of this work, still ongoing for certain parts, an editorial structure in five series has emerged, responding to a reasoning both chronological and thematic in nature: Series I and III contain D'Alembert's scientific works, Series II is dedicated to his encyclopedic work, Series IV collects his philosophical, historical and literary writings, and Series V all his correspondence, active et passive $e^{4}$. The new edition coordinated by I. Passeron, initially supported by the French public research body, the CNRS, and today under the aegis of the Academy of Sciences' D'Alembert committee, tangibly got off the ground in 2002 with the publication of a first opus; at the time of writing, seven volumes have now been published and two digital projects are about to be released.

This publishing project, and the research team it has assembled, has, along with some other studies, widely contributed to a significant renewal in the historiography of the writings of a thinker who remained largely unknown until the beginning of the 1980s, and whose work, for large parts of it, is still waiting to be explored today ${ }^{5}$. Other recent initiatives are making important additions to the edifice, such as the preparation of a critical edition in German of 
D'Alembert's Essai sur les élémens de philosophie (within the framework of the project "The Normativity of Formal Knowledge: The Exact Sciences, Equality and Situated Universalism in the 18th Century" carried out by the University Goethe of Frankfort/Main, led by M. Epple). The seven articles featured in this issue shed light on this renewal in all the diversity of the topics addressed and methodological approaches employed. Beforehand, the present introduction will endeavour to take stock as comprehensively as possible of the research and editorial projects dedicated to D'Alembert over the course of these last three or four decades.

\section{Archives}

The evolution in our understanding of D'Alembert and his work is largely due to the significant archival research conducted since the beginning of the 1990s. As already stated, the preliminary work carried out within the framework of the project to publish his Euvres complètes has especially consisted in establishing a primary inventory of the author's manuscripts ${ }^{6}$. These can be presented in the form of three principal document sets: the manuscripts resulting from D'Alembert's activities as a member of the Royal Academy of Sciences in Paris, the Academy of Sciences and Literature in Berlin and the French Academy and the writings he presented there - the overwhelming part of which are currently conserved in the holdings of the respective institutions (the archives of the "Académie des Sciences", "Académie française" and those of the "Berlin-Brandenburgische Akademie der Wissenschaften"); the manuscripts he sent to private recipients; the manuscripts he stored in his home and which were transferred to Condorcet in his capacity as sole legatee.

The latter have mostly been bequeathed to the Institut de France library together with those written by Condorcet ${ }^{7}$. They alone represent more than half of the ten thousand or so handwritten manuscripts by D'Alembert uncovered to date. A study of this collection, which was in such disarray that it often required page by page examination, along with dating analyses revealed that the greater part is posterior to 1770 . Contents include notes, rough drafts and unpublished hand-written texts. Many relate to his Opuscules mathématiques, but there are also documents concerning the Mélanges de littérature, d'histoire ou de philosophie, and letters and numerous manuscripts linked to his duties as the French Academy's permanent secretary, especially preliminary versions of the Eloges lus published in 1779. Another part of the manuscripts bequeathed to Condorcet has been transferred into private collections and the holdings of various public libraries, including the French National Library, which conserves notes pertaining to mathematics, manuscripts on celestial mechanics, corrected proofs (dating from the 1770s) of entries from the Encyclopédie, as well as fragments of a memoir D'Alembert wrote about himself, written in his own hand most probably near the end of his life and which constitutes one of the principal sources on his formative years that we dispose of $^{8}$.

The task of finding the whole array of manuscripts corresponding to the letters sent by D'Alembert has been one part of a broader project to establish an analytical inventory of his active and passive correspondence, led by I. Passeron, in collaboration with A.-M. Chouillet and J.-D. Candaux. Today, the inventory, which I. Passeron presents in this issue, can be consulted in paper form $(O . C ., \mathrm{V} / 1,2009)$ and online ${ }^{9}$, and describes more than 2300 letters exchanged. It is the result, once again, of patient work on archives undertaken in libraries all over the world, in private collections and on specialised sales catalogues. This work is ongoing and has led to new letters being uncovered.

The different scientific manuscripts thus identified, whether they have been materially uncovered or we only have indirect proof of their existence, cover the entire length of this career, from his first unpublished writings to the unfinished version of a ninth volume of his 
Opuscules mathématiques. The information alone that they provide on the two extremities of his career is priceless. We learn about his training in mathematics, with testimony on his readings of Newton, Jean Bernoulli, Guisnée, De Gua (De Gandt 2005; Peiffer 2005; O.C., $\mathrm{I} / 4 \mathrm{a}, 2007$ ), and about the subjects he first conducted research on (integral calculation and resistance of solid bodies). At the other end of his life, we gain insights into his last reflections on his favourite subjects (the problem of string vibration and the propagation of sound, the principles of mechanics, celestial mechanics, hydrodynamics, optics, integral and differential calculus, probability), including a sort of testament laying out the contributions he brought to the field of hydrodynamics. Between these two extremities, other manuscripts have greatly enriched our understanding of D'Alembert's contributions, the stance he took in different disputes and on claims of priority, modifying our perception of certain sequences in the scientific history of that period. A case in point would be the unpublished texts - edited, annotated and presented by M. Chapront-Touzé in $(O . C$., I/6, 2002) - on the three-body problem and the theory of the moon in the context of the Newtonian crisis during the years 1747-1749, or a Latin copy, dated 1749, of the first version of a work published three years later (the Essai d'une nouvelle théorie de la résistance des fluides) the study of which has provided proof of D'Alembert's fundamental contribution, before Euler, to the mathematisation of the motion of fluids (Grimberg, 1998).

Still more recently, the archives have thrown up more surprising elements, not this time related to one aspect or another of D'Alembert's scientific contributions, but regarding his own identity, that of his nanny and the master of his boarding school, shedding new light on what we thought we knew regarding his origins, his immediate circle and the friendships he forged in his youth. These findings, presented in this issue by F. Launay, are the result of the laborious and systematic investigation of parish archives, library holdings and documents stored in the "Archives nationales" in Paris and other local archives (notarial studies compiling baptismal certificates, marriage contracts, inventories after death, etc.).

The findings show to what extent archival research related to D'Alembert, whether it concerns scientific texts, letters or civil status documents, has enriched our understanding of his work, his thinking, the disputes he took a stance on, as well as of the man himself and his place in the social and intellectual context of the period. Let's now consider how our perspective on his scientific work has evolved.

\section{Mathematics and the physico-mathematical sciences}

Although D'Alembert's mathematics and physico-mathematical work had a striking impact on his time, in the 19th century they were considered obscure and surpassed by the findings of Euler, Laplace and Lagrange. However, numerous and for the most part recent studies have called into question this distorted vision and restored D'Alembert to his rightful place in the history of mathematical sciences, in line not only with the real contributions he made, but also with his notable and underestimated influence on the subsequent generation of mathematicians, namely Condorcet, Lagrange, Laplace, or even Bossut. This is what is shown in the work by T. L. Hankins (1970), or by R. Taton and A. P. Yushkevich (1980) in their edition of the correspondence between Euler and D'Alembert for the Leonhardi Euleri Opera Omnia, both of which constituted an important step in the research on the French mathematician. Another important step in this direction has since been made by the dynamic editorial team of the Euvres complètes and in particular by P. Crépel's studies into D'Alembert's late work, essentially made up of the nine volumes of his Opuscules mathématiques (eight were published between 1761 and 1783, one remained unpublished) which historians up until the last fifteen years knew very little about, but in which D'Alembert exposed the essential part of the research he undertook in the latter years of his scientific 
career. Two of these volumes (the first and third) have already been published (O.C., III/1 and III/3).

In the field of mathematics, C. Gilain's work has given rise to the most significant advances. He has published a summary of his findings, accompanied by six texts by D'Alembert, two of which were previously unpublished, in (O.C., I/4a, 2007). These address the problem of integrating rational or irrational differential expressions with one variable, the problem of integrating ordinary differential equations and systems of equations, the (first) demonstation of the fundamental theorem of algebra and the dispute which opposed D'Alembert to Euler on the subject of logarithms with negative or imaginary quantities. This whole series of texts reveals the breadth and coherence of D'Alembert's work on pure mathematics in the years from 1740 to 1750 , contrary to the widespread misconception that this field, to which he did not dedicate a book as such, was for him only a tool he developed in response to his needs in mixed mathematics.

Other studies have given us a greater insight into the subtle relationship between mathematical analysis and mechanics in D'Alembert's work: two fields with porous borders, interacting on one another, but with their own discernible logic. A good illustration of this is given by the theory of partial differential equations, a new branch of mathematics which has been the subject of several studies over the last three decades (Demidov 1982; Engelsman 1984a, 1984b; Grimberg 1998) all of which agree on the fact - and this is another important historiographical evolution - that D'Alembert should be considered its founder: firstly, for having introduced a new tool - partial differential calculus - in the translation of mechanical problems into equations (loaded hanging string, string vibration, atmospheric motion, resistance and flow of fluids) and secondly, for his attempts at integrating the (partial differential) equations thus obtained. The study of his late work (Jouve 2008; Guilbaud and Jouve 2010) has brought out another, very interesting aspect: D'Alembert was among the first, at the end of the $1760 \mathrm{~s}$, to embark on a systematic study of partial differential equations considered as a mathematical object without reference to any physical context. With these equations, D'Alembert therefore made a fundamental contribution to the emergence of a new branch of pure mathematics while adding an important building block to the edifice of physico-mathematical sciences, namely a first step towards mathematising what today we call continuum mechanics (Truesdell 1954; Grimberg 1998; Darrigol 2005; Guilbaud 2007). Following the same line of reasoning, the study of D'Alembert's last works dedicated to the problem of vibrating strings - G. Jouve provides an overview of the history in this issue along with his latest findings - enables us to follow his progress on the physical question pertaining to the propagation of sound and witness a notable change in his position within the context of a mathematical dispute with Euler, Daniel Bernoulli and Lagrange concerning the properties of the concept of function (Jouve 2008 ; Guilbaud and Jouve 2010).

D'Alembert's work in the field of mixed mathematics has also been the subject of substantial research, profoundly revisiting and providing a much more comprehensive view of his contributions to astronomy, solid and fluid mechanics, acoustics and optics.

This is the case, in celestial mechanics, of the edition already cited that M. Chapront-Touzé (O.C., I/6, 2002) has dedicated to D'Alembert's thinking about the moon and how he progressively worked out his lunar theory in the context of the Newtonian crisis in the years 1747-1749 and his rivalry with Clairaut and Euler; we could also cite another edition he prepared in collaboration with J. Souchay (O.C., I/7, 2006), dedicated to D'Alembert's decisive theoretical contribution to the problem of the precession and nutation of the Earth's axis (1749).

All of these studies have also created an opening in which it becomes possible to question the point of view expressed by C. A. Truesdell in his essays on the history of rational mechanics, published notably in his introductions to volumes 11,12 and 13 in series II of the 
Opera Omnia of Euler where, despite his extensive research into the history of the discipline, his manifest aversion towards the French mathematician has lastingly contributed to distorting the extent of D'Alembert's input in this field ${ }^{10}$. The edition (O.C., I/7, 2006), as well as those of (Wilson 1987; Nakata 2000; Verdun 2015), thus provide a more objective vision of the links between D'Alembert's and Euler's theories of precession - and the influence of the former on the latter - and the relations, also passed over in (Truesdell 1954), between the strictly dynamic aspects linked to D'Alembert's mechanics of rigid bodies and the preliminary studies Euler devoted to this question. For his part, J. Viard (2002) insists on the presence, overlooked by C. Truesdell (1968), of the angular momentum theorem and the conservation of the angular momentum in D'Alembert's Traité de dynamique ( $1^{\text {st }}$ éd. $1743 ; 2^{\mathrm{d}}$ éd., 1758).

The classic study that T. L. Hankins (1970) devoted to the origin and uses of the celebrated principle expounded by D'Alembert in this same Traité de dynamique, along with other research papers (Fraser 1985; Vilain 2000a,b; Firode 2001; Nakata 2002; Viard 2003; Schmit 2013; Caparrini and Fraser 2013) that have appeared since, have led to an important reappraisal of D'Alembert's contribution to the development of rational mechanics in the 18th century. Although often overlooked or underrated (Truesdell 1960a, 1960b; Maltese 1992; Williams and Caparrini 2008), the originality and extent of D'Alembert's contribution to the field of mechanics becomes visible once care is taken to compare his approach with that of his contemporaries, such as Clairaut and Euler, without dissociating the strictly technical aspects of the dalembertian epistemology. Similarly (Le Ru 1994; Firode 1996, 2001; Schmit 2009) show that by submitting this epistemology to close examination - it comes particularly to the fore in his a priori demonstrations of principles or in his critique and contextualisation of a causal approach to physics - we are better able to grasp D'Alembert's choice of principles and problem-solving methods. This is what C. Schmit brings to light in this issue, regarding dynamics in solids in the context of research undertaken at the Royal Academy of Sciences in Paris between 1735 and 1743.

D'Alembert's contribution to hydrodynamics, principally known via his Essai d'une nouvelle théorie sur la résistance des fluides (1752), has also begun to shine more brightly in current historiography, beginning with the reappraisal of his Traité de l'équilibre et $d u$ mouvement des fluides (1744, $1^{\text {st }}$ éd.; 1770, $2^{\mathrm{d}}$ éd.). All but ignored in the studies by Truesdell (1954), it has been restored to its rightful place in recent studies on fluid mechanics in the 18th century (Darrigol 2005; Calero 2008; Guilbaud, 2008b; O.C., V/2, pp. cv-cxx). Recent literature on D'Alembert's late work, notably the memoirs published in volumes V and VIII of his Opuscules mathématiques, has uncovered there a vast and rich body of research that has been totally neglected until now, and by so doing has revealed the breadth and given new coherence to D'Alembert's whole body of work in this field (Coste and Massot 2002; Guilbaud 2007, 2008a). F. Chambat's current research project on the Réflexions sur la cause générale des vents (1747), known for the prize it won for its author, but nevertheless very rarely studied, is also likely to produce important new findings $(O . C ., \mathrm{V} / 2$, pp. cviii-cix).

However, probably the most surprising historiographic evolution comes from the research conducted by F. Ferlin who, in the critical edition of the third volume of Opuscules mathématiques (O.C., III/3, 2011), has unearthed a general and coherent treatise, the first of its kind, on the theory of optical aberrations in achromatic telescopes. Analysis of the treatise, the principal elements of which F. Ferlin exposes in this issue, has revealed that D'Alembert detected, in parallel with the work Clairaut was doing on the subject, several off-axis or Seidel aberrations, as they became known, more than a century before this German savant had published his classic memoir on the subject. This all leads to a serious renewal of the history of geometrical optics in the middle of the 18th century and the role played by D'Alembert in this field. 


\section{Interactions, diffusion, publication and circulation of knowledge}

As we recalled at the beginning of this introduction, D'Alembert was not only a man of science, but also a man of letters, an encyclopedist and a philosopher. One important axis of current research is based on the study of possible interactions between these different aspects of his work, the different circles he frequented and evolved in, as well as his networks and the means by which he exchanged, diffused and published his ideas. Progress in this perspective has been particularly significant. In part, this research falls within a broader movement which over the last thirty years has contributed to profoundly renewing the study of the networks which enabled knowledge and ideas to circulate during the Enlightenment period (Passeron 2008), particularly through academic circles (Hahn 1971; Brian and Demeulenaere-Douyère 1999, 2002; Halleux 2002; McClellan 2003), epistolary exchanges (Beaurepaire 2003) and society gatherings (Lilti 2005) ${ }^{11}$. As we will see just after, research in this domain has not overlooked the Encyclopédie in general or the particular case of D'Alembert.

The work carried out and coordinated by I. Passeron on D'Alembert's epistolary exchanges is at the forefront of this progress in research. The inventory of his active and passive correspondence $(O . C ., \mathrm{V} / 1)$, mentioned earlier for the underlying archival work it required, constitutes in itself an incomparable research tool, documenting exchanges on scientific, philosophical, political, academic or even sentimental matters with a network of more than 420 correspondents from all over Europe. The first volume of the critical edition of this correspondence $(O . C ., \mathrm{V} / 2)$ collects, presents and comments on the letters sent and received between the years 1741 and 1752 . It perfectly illustrates how the letters can shed light on our understanding of D'Alembert's work and activity during a period characterised for him by the publication of his first treatises, important scientific disputes, the preliminary phase of the Encyclopédie and his struggle in the ideological battles that would mark the editorial history of this work. As I. Passeron points out here in this issue, this corpus is important for the insights it affords us into the political, ideological and scientific landscape of the Enlightenment as well as for what it tells us about the different roles D'Alembert played in relation to his peers and depending on the nature of the work in question. Reading the letters gives us a deeper understanding of his thinking, and we are thus impatient to read the subsequent volumes of the critical edition of letters. In the meantime, the online digital interface, set up in addition to the print format, will give anyone the possibility to consult the different aspects of the inventory and keep abreast of the latest letters uncovered ${ }^{12}$.

The forthcoming publication of a new volume of the Euvres completes (O.C., III/11), coordinated by M. Jacob, promises to shed new light on another aspect of D'Alembert's work, namely his activity as member of the Academy of Sciences. The critical edition of the whole set of reports submitted by the expertise commissions (who pronounced on texts and machines) he took part in, on the one hand, and the analysis of elements which testify to his efforts to bring about reform in 1769, the year he served as director of the institution, on the other, will give a palpable sense of this activity.

We already knew that D'Alembert's relations with the Berlin Academy of Science and Literature and the Royal Academy of Sciences in Paris were not without their ups and downs. This is shown in the study of his polemics with Euler on the subject of integral calculus (O.C., vol. $\mathrm{I} / 4 \mathrm{a})$, the precession of the equinoxes $(O . C$., vol. $\mathrm{I} / 7$, p. xcix-cxii), vibrating string problem and the Berlin Academy's 1750 prize for work on fluids (O.C. vol. III/1; vol. V/2), and furthermore his quarrels with Clairaut (Badinter 2002, p. 208-209). The deterioration in his relations with the two academies is in part what explains the notable shift in his publication strategy regarding his scientific work over the course of the 1750s. This important change took different forms (Crépel 2008; O.C., III/1, 2009, p. xv-xxxiii): firstly, by making use of entries in the Encyclopédie to assert certain priorities or make public new findings; 
secondly, through recourse to certain journals to present his work or fuel a polemic with Clairaut (on the return of Halley's comet, the three-body problem, or the lunar tables between 1757 and 1762) or with Daniel Bernoulli (on inoculation in 1761-1762); thirdly, by publishing his Opuscules mathématiques, the principal medium for the diffusion of his scientific work from the beginning of the $1760 \mathrm{~s}$.

From a methodological point of view, it is important to note that the study of these publishing strategies ${ }^{13}$ has also greatly enhanced our understanding of D'Alembert's work, whether this be as to his motivations faced with a given context or aiming to reach a particular readership, on the links that may bind together certain parts of his work, or on what these elements tell us about the man himself, his way of reasoning and how he fits into the intellectual life of his time. It is also in this perspective that, in this issue, M. Epple and D. Comtesse have chosen to juxtapose D'Alembert's work as a translator and the critical translation of his Essai sur les élémens de philosophie into German. This approach to D'Alembert's strategies of course also raises questions relative to his contributions to the Encyclopédie.

Indeed, advances in research dedicated to D'Alembert's scientific output have shown that the Encyclopédie represents a turning point, between an initial phase (period marked by his major treatises and academic memoirs) and his late work, published for the greater part in the form of his Opuscules $^{14}$ : the first six memoirs collected in the first volume of the Opuscules mathématiques (1761) developed directly out of outlines published among the pages of the first nine volumes of the Encyclopédie (O.C., III/1, 2009). As we just mentioned, D'Alembert took full advantage of the tribune that this offered to him to defend certain findings, claim their priority over others and prolong old disputes ${ }^{15}$. Other studies have shown how the savant drafted some of his articles by drawing on selected extracts from the prefaces to his first treatises (such as the Traité de dynamique, or the Essai d'une nouvelle théorie de la résistance des fluides), then subsequently how some of these revamped compositions could in turn become the basis of other writings, such as the Essai sur les Elémens de philosophie ${ }^{16}$.

Strictly speaking, D'Alembert's contribution to the Encyclopédie ou Dictionnaire raisonné des sciences, des arts et des métiers has already been the subject, more or less directly, of numerous studies concerned with addressing a particular field ${ }^{17}$, a particular problem or question $^{18}$, or a particular entry ${ }^{19}$ - without forgetting of course the famous "Discours préliminaire" published at the front of the first volume, and studied more often than the rest ${ }^{20}$. Even though research in this area has been dynamic and the findings rich, the analysis of D'Alembert's immense contribution, estimated today at around 1800 entries of which three quarters fall within the fields of mathematics and physics (as the period defined it), still remains a major undertaking. In addition, the project to carry out a systematic study of this corpus faces serious methodological obstacles linked to the tumultuous editorial history of the work, the complex ways in which it was put together, the heterogeneity of the content, the diversity of the contributors as well as multiple internal referencing systems running through the whole encyclopedic project. In a word, circumscribing D'Alembert's contribution is in itself problematic to the extent that numerous questions regarding authorial attribution remain inconclusive, and that it is often difficult to extract entries (or parts of an entry) from the particular context of the Encyclopédie.

These obstacles, however, are in the process of being removed thanks to a highly ambitious project, the Edition Numérique Collaborative et CRitique of the Encyclopédie (ENCCRE) ${ }^{21}$, led by the D'Alembert research group (Groupe D'Alembert) with the backing of the Academy of Science and other partners, including the "Société Diderot". This edition, a first version of which has been online since 19 October 2017 and whose objectives fall perfectly in line with those set out in the pioneering research of J. Proust (1962/1995), J. Lough (1968) and R. N. Schwab (1971-1972), must allow the encyclopedists' contributions to be analysed, annotated 
and presented in their original context, but must also provide the tools necessary to facilitate study of the methodological questions and ideological stakes specific to this corpus, including: the authorial attribution of entries, or their sources and/or their re/appearance in anterior and posterior dictionaries and encyclopedias. The ongoing work on D'Alembert, as A. Guilbaud shows in this issue, has already achieved significant progress as regards the compiling of a reasoned, annotated inventory of all his contributions. It also offers the prospect of elaborating, over time, a critical edition of this corpus able to account for its inscription within different networks: the encyclopedic network itself, the circulation of knowledge embodied in the 18th century by the lexicographic corpus, and, of course, the network composed by D'Alembert's own lifetime of work, at the intersection between science, literature and philosophy.

\section{REFERENCES}

Abbreviations (the original titles in French have been retained throughout) :

O.C., I/6: D’Alembert, J. Le Rond (2002), Premiers textes de mécanique céleste (1747-1749), Euvres complètes, vol. I/6, M. Chapront-Touzé (ed.) (Paris: CNRS Editions).

O.C., I/7 : D’Alembert, J. Le Rond (2006), Précession et nutation (1749-1752), Euvres complètes, vol. I/7, M. Chapront-Touzé and J. Souchay (ed.) (Paris: CNRS Editions).

O.C., I/4a : D’Alembert, J. Le Rond (2007), Textes de mathématiques pures (1745-1752), Euvres complètes, vol. I/4a, C. Gilain (ed.), (Paris: CNRS Editions).

O.C., III/1 : D’Alembert, J. Le Rond (2008), Opuscules mathématiques, 1761, Euvres complètes, vol. III/1, P. Crépel, A. Guilbaud, and G. Jouve (ed.) (Paris: CNRS Editions).

O.C., III/3 : D’Alembert, J. Le Rond (2011), Opuscules mathématiques, tome 3 (1764), Euvres complètes, vol. III/3, F. Ferlin (ed.) (Paris : CNRS Editions).

O.C., V/1 : D'Alembert, J. Le Rond (2009), Inventaire analytique de la correspondance (1741-1783), Euvres complètes de D'Alembert, vol. V/1, I. Passeron (ed.) with A.-M. Chouillet and J.-D. Candaux (Paris : CNRS Editions).

O.C., V/2 : D’Alembert, J. Le Rond (2009), Correspondance générale (1741-1752), Euvres complètes, vol. V/2, I. Passeron (ed.) (Paris : CNRS Editions).

Badinter, E. (1999) Les Passions intellectuelles I, Désirs de gloire (1735-1751), (Paris : Fayard).

Badinter, E. (2002) Les Passions intellectuelles II, Exigence de dignité (1751-1762), (Paris : Fayard).

Badinter, E. (2007) Les Passions intellectuelles III, Volonté de pouvoir (1762-1778), (Paris : Fayard).

Beaurepaire, P.-Y. (2005) La franc-maçonnerie, observatoire des trajectoires et des dynamiques sociales au $18^{\mathrm{e}}$ siècle, Dix-huitième siècle, 37, 17-30.

Brian, E. and Demeulenarere-Douyère, C. (ed.) (1999) Histoire et mémoire de l'Académie des sciences. Guide de recherches (Paris : Ed. Lavoirisier Tech \& Doc).

Brian, E. and Demeulenarere-Douyère, C. (ed.) (2002) Règlement, usages et science dans la France de l'Absolutisme (Paris : Ed. Lavoirisier Tech \& Doc).

Calero, J. S. (2008), The Genesis of Fluid Mechaniscs 1640-1780 (Dortrecht : Springer).

Caparrini, S. and Fraser, C. (2013) Mechanics in the Eighteenth Century, in: Buchwald J. and Fox R. (eds) Oxford Companion to the History of Physics (Oxford: Oxford University Press), 358-405.

Cernuschi A., (1996) D'Alembert pris au jeu de la musique. Ses interventions musicographiques dans l'Encyclopédie, Recherches sur Diderot et sur l'Encyclopédie, 21, 145-161.

Chouillet, A.-M. (2002), Liste chronologique des œuvres imprimées de D’Alembert, in (Michel and Paty, 2002, pp. 95-114).

Chouillet, A.-M., De Gandt, F. and Passeron, I. (1998) L'édition des Euvres complètes de D'Alembert (17171783), Gazette des Mathématiciens, 77, 59-71.

Coste, A. (2009), Air, the making of, Recherches sur Diderot et sur l'Encyclopédie, 44, 9-14.

Coste A., Massot M. (2002) La notion de fluide chez D’Alembert à la lumière des Opuscules mathématiques et de la correspondance, in: Sciences, Musique, Lumières. Mélanges offerts à Anne-Marie Chouillet, U. Köllving and I. Passeron (ed.), 83-91.

Crépel, P. (2005), Où en est-on de l'édition des Euvres complètes de D'Alembert ?, Bulletin de la Société Française d'Etude du Dix-Huitième Siècle, 58.

Crépel, P. (2006a) La "physique" dans l'Encyclopédie, Recherches sur Diderot et sur l'Encyclopédie, 40-41, 251283. 
Crépel, P. (2006b), Qu'y a-t-il de nouveau dans l'œuvre scientifique de D'Alembert?, in: Sarah Carvallo et Sophie Roux (ed.), Du nouveau dans les sciences, Recherches sur la philosophie et le langage, 24, 171-223.

Crépel, P. (2006c), Les dernières perfidies de D’Alembert, Mathématiques \& sciences humaines, vol. 176, 2006, 61-87.

Crépel, P. (2008), Républiqu(e)s des savants et stratégies de publication, Dix-huitième siècle, 40, 115-128.

Crépel, P. (2009a) Nouvel état de l'édition des Cuvres complètes de D'Alembert, Bulletin de la Société Française d'Etude du Dix-Huitième Siècle, 71, 23-24.

Crépel, P. (éd.) (2009b), D’Alembert. Mathématicien des Lumières, Les génies de la science, 39, 19-94.

D’Alembert, J. Le R. (1799) Euvres posthumes de D’Alembert, C. Pougens (ed.), 2 vol. (Paris : Pougens).

D'Alembert, J. Le R. (1805) Euvres philosophiques, historiques et littéraires de D'Alembert, J.-F. Bastien (ed.), 18 vol. (Paris: Bastien).

D’Alembert, J. Le R. (1821-22) Euvres de d'Alembert, A. Belin (ed.), 5 vol. (Paris: Bossange).

D’Alembert, J. Le R. (2017) Versuch über die Elemente der Philosophie (Hamburg: Felix Meiner Verlag).

Darrigol, O. (2005) Worlds of Flow. A history of hydrodynamics from the Bernoullis to Prandtl (Oxford : Oxford University Press).

De Gandt, F. (1996) La Physique de d'Alembert dans 1'Encyclopédie, Recherches sur Diderot et sur l'Encylopédie, 21, 99-112.

De Gandt, F. (2005) Les études newtoniennes du jeune D'Alembert, Recherches sur Diderot et sur l'Encyclopédie, 38, 177-190.

Demidov, S. (1982) Création et développement de la théorie des équations différentielles aux dérivées partielles dans les travaux de J. d'Alembert, Revue d'histoire des sciences, 35/1, 3-42.

Emery, M. and Monzani, P. (éd.) (1989), Jean d'Alembert, savant et philosophe : portrait à plusieurs voix (Paris : Editions des archives contemporaines).

Engelsman, S. B. (1984a) Families of Curves and the Origins of Partial Differentiation (Amsterdam : Elsevier). Engelsman, S. B. (1984b) D’Alembert et les équations aux dérivées partielles, Dix-huitième siècle, 16, 27-37.

Ferret, O. (2008), Les « réflexions philosophiques » dans les éloges académiques dans les éloges académiques de D’Alembert : le cas de l'Eloge de Bossuet, Bollettino di storia delle scienze matematiche, XXVIII/ 2, 255-272.

Ferret O., Guilbaud A., Passeron, I. (2012) Pleins et déliés dans les manuscrits de D'Alembert, Genesis, 34 , 2012, 67-82.

Firode, A. (1996), Les Lois du choc et la rationalité de la mécanique selon d'Alembert, Recherches sur Diderot et sur l'Encyclopédie, 21, 113-129.

Firode A. (2001) La dynamique de D'Alembert (Paris-Montréal : Vrin-Bellarmin).

Firode, A. (2006), Les catégories de la mécanique dans l'Encyclopédie, Recherches sur Diderot et sur l'Encyclopédie, 40-41, 179-192.

Fraser, C. (1985) D'Alembert' Principle : The original Formulation and Application in Jean d' Alembert' Traité de dynamique, Centaurus, 28, 31-61 (Part 1), 145-159 (Part 2).

Gilain C. (2010) La place de l'analyse dans la classification des mathématiques : de l'Encyclopédie à la Méthodique, Recherches sur Diderot et sur l'Encyclopédie, n 45 (2010), pp. 109-128.

Grimberg, G. (1998), D’Alembert et les équations aux dérivées partielles en hydrodynamique, thèse de doctorat, université Paris 7.

Grimsley, R. (1963) Jean D’Alembert (1717-1783) (Clarendon Press).

Guilbaud, A. (2007) L'œuvre tardive de D'Alembert en hydrodynamique, thèse de doctorat, université Lyon 1.

Guilbaud, A. (2008a) La République des hydrodynamiciens de 1738 jusqu'à la fin du $18^{\mathrm{e}}$ siècle, Revue DixHuitième Siècle, 40, 153-171.

Guilbaud, A. (2008b) La loi de continuité de Jean Bernoulli à D'Alembert, Bollettino di storia delle scienze matematiche, XXVIII/2, 183-200.

Guilbaud A. (2012) Le problème de la résistance des fluides dans l'Encyclopédie et l'Encyclopédie méthodique de Mathématiques, in: Suzanne Féry (ed.), Aventures de l'Analyse de Fermat à Borel : Mélanges en l'honneur de Christian Gilain (Nancy : Presses universitaires de Nancy), pp. 367-417.

Guilbaud, A. (2017), The digital edition of D'Alembert's correspondence, in: M.-T Bergato, E. Neuenschwander and I. Passeron (ed.), Mathematical Correspondences and Critical Editions (Springer, Birkhaüser).

Guilbaud, A. and Jouve, J. (2010) La résolution des équations aux dérivées partielles dans les Opuscules mathématiques de D'Alembert (1761-1783), Revue d'histoire des mathématiques, 15/1, 59-122.

Hahn, R. (1971) The Anatomy of a Scientific Institution. The Paris Academy of Sciences, 1666-1803 (Berkeley: University of California Press).

Halleux, R. (ed.) (2002) Les Publications de l'Académie royale des sciences de Paris, 2 vol. (Brepols).

Hankins, T. L. (1970) Jean d'Alembert, Science and the Enlightenment (Oxford: Clarendon Press, Oxford University Press).

Henry, C. (1887) Euvres et correspondance inédites de d'Alembert (Paris : Perrin et Cie).

Jouve G. (2008) Le rôle de D'Alembert dans les premiers pas d'une étude programmatique des équations aux 
dérivées partielles (1760-1783), in D’Alembert, les Lumières, l'Europe, Bollettino di Storia delle Scienze Matematiche, anno XXVIII, fasc. 2, décembre 2008, pp. 167-182.

Lilti, A. (2005) Le monde des salons. Sociabilité et mondanité à Paris au 18 e siècle (Paris: Fayard).

Le Ru, V. (1994) D’Alembert philosophe (Paris : Vrin).

Lough, J. (1968), Essays on the Encyclopédie, London, Oxford University Press.

Maheu, G. (1967) La vie et l'œuvre de Jean D'Alembert. Etude bio-bibliographique, Thèse, Paris, Ecole pratique des hautes études.

Maltese, G. (1992). La storia di F=ma. Le seconda legge del moto nel XVIII secolo (Florence : Leo S. Olschki).

Michel, A. and Paty, M. (éd.) (2002) Analyse et dynamique. Etudes sur l'ouvre de D'Alembert (Canada: Les Presses universitaires de Laval).

McClellan, J. (2003) Specialist Control: the Puplications Committee of the Academie royale des sciences (Paris), 1700-1793 (Philadelphia : American Philosophical Society).

Nakata, R. (2000), D'Alembert's Second Resolution in Recherches sur la Précession des Equinoxes : Compare with Euler, Historia Scientiarum, 10 (1), 52-76.

Nakata, R. (2002) The General Principles for Resolving Mechanical Problems in D'Alembert, Clairaut and Euler, Historia Scientiarum, 12 (1), 18-42.

Pappas, J. (1986) Inventaire de la correspondance de d'Alembert, SVEC 245, 131-276

Pappas, J. (1989) Supplément à l'Inventaire de la correspondance de D’Alembert, SVEC 267, 283-289.

Passeron, I. (1996), "Savoir attendre et douter » : l'article Figure de la Terre, Recherches sur Diderot et sur l'Encyclopédie, 21, 131-144.

Passeron, I. (2005) Le mémoire de D’Alembert sur lui-même, Recherches sur Diderot et sur l'Encyclopédie, 38, 17-31.

Passeron, I. (2006) D’Alembert refait le MONDE (Phys.) : parcours dans les mathématiques mixtes, Recherches sur Diderot et sur l'Encyclopédie, 40-41, 155-177.

Passeron, I. (ed) (2008) La République des Sciences, Dix-huitième siècle, 5-357.

Passeron, I. (2009) Trou d'air : où est passée l'aérologie ?, Recherches sur Diderot et sur l'Encyclopédie, 44, 163-182.

Passeron, I. (2015) Correspondance générale (1741-1752), in : Jean Le Rond D’Alembert, Euvres complètes, vol. V/2 (Paris : CNRS Editions).

Paty, M. (2002) Les recherches actuelles sur D'Alembert. A propos de l'édition de ses Euvres complètes, in: (Michel and Paty, 2002, p. 25-93).

Peiffer, J. (2005) Le « Traité de Géométrie » de Varignon et l'apprentissage mathématique du jeune D’Alembert, Recherches sur Diderot et sur l'Encyclopédie, 38, 125-150.

Proust, J. (1962/1995) Diderot et l'Encyclopédie ; rééd. Albin Michel, Paris.

Schmit C. (2009) Force d'inertie et causalité, Archives Internationales d'Histoire des Sciences, Vol. 59, n 162, 97-155.

Schmit C. (2013) Sur l'origine du principe général de Jean Le Rond D’Alembert », Annals of Science, Vol. 70 (4), 493-530.

Schmit C. (2014), Méchanique, Statique, Dynamique. Répartition du savoir et définitions dans l'Encyclopédie. $1^{\text {ère }}$ partie, Recherches sur Diderot et sur l'Encyclopédie, ${ }^{\circ}$ 49, 224-258.

Schmit C. (2015), Méchanique, Statique, Dynamique. Répartition du savoir et définitions dans l'Encyclopédie. $2^{\mathrm{ème}}$ partie », Recherches sur Diderot et sur l'Encyclopédie, $\mathrm{n}^{\circ}$ 50, 273-299.

Schwab, Richard N., with Rex, Walter E. and Lough, J. (1971-1972) Inventory of the Encyclopédie, Oxford, SVEC, 7 vol.

Truesdell, C. (1954) Rational Fluid Mechanics, 1687-1765, in: Leonhardi Euleri Opera omnia, Vol. II.12 (Zürich : Orell Füssli)

Truesdell, C. (1960a) The Rational Mechanics of Flexible or Elastic Bodies, 1638-1788, in: Leonhardi Euleri Opera Omnia, Vol. II. 10-11 (Zürich: Orell Füssli)

Truesdell, C. (1960b) A Program toward Rediscovering the Rational Mechanics of the Age of Reason, Archive for History of Exact Sciences, 1 (1), 3-36.

Truesdell, C. (1968), Whence the Law of Moment of Momentum?, in: Truesdell C. (ed.), Essays in the History of Mechanics (Berlin Heidelberg New York : Springer), 239-271.

Verdun, A. (2015). Leonhard Eulers Arbeiten zur Himmelsmechanik (Berlin Heidelberg: Springer-Spektrum) Viard J. and Ismaël-Youssouf, D. (1997), Les relations entre élasticité et dureté dans le Traité de Dynamique sont-elles compatibles avec celles de l'Encyclopédie ?, Recherches sur Diderot et sur l'Encyclopédie, 22, 123145.

Viard, J. (2002) Le principe de D'Alembert et la conservation du 'moment cinétique' d'un système de corps isolés dans le Traité de dynamique », Physis, 39, 1-40.

Vilain, C. (2000a) La question du "centre d'oscillation" de 1660 à 1690, Physis, 37, 21-51.

Vilain, C. (2000b) La question du "centre d'oscillation" de 1703 à 1743, Physis, 37, 439-466. 
Williams K. and Caparrini S. (2008), Discovering the Principles of Mechanics 1600-1800. Essays by David Speiser (Basel, Boston, Berlin : Birkhäuser.

Wilson, C. (1987) D'Alembert versus Euler on the Precession of the Equinoxes and the Mechanics of Rigid Bodies, Archive for History of Exact Sciences, 37 (3), 223-273.

Yushkevich A. P. and Taton, R. (1980) Leonhardi Euleri Commercium Epistolicum, Opera Omnia, IVa (5) (Bâle : Birkhäuser).

1 We could also mention the monograph by (Grimsley 1963).

2 Let's also acknowledge the international symposium held during the bicentenary celebrations on the 15-18 June 1983 of the death of D'Alembert (Emery and Monzani, 1989) and which played a role in the emergence of this publishing project. The work of the D'Alembert Research Group is overseen by an editorial committee, the membership of which has evolved over time. The following is the list of members from 1992 until the beginning of the 2000s: E. Brian, A.-M. Chouillet, M. Chapront-Touzé, P. Crépel, F. De Gandt, C. Gilain, B. Morando, I. Passeron, M. Paty, J. Peiffer, J. Viard. For further information on the current progress of the D'Alembert project and the current members of the committee, refer to the website http://dalembert.academie-sciences.fr.

3 See (Chouillet, 2002).

4 The letters sent by D'Alembert compose the active correspondence and the letters received compose the passive one. On the criteria of definition and selection of D'Alembert's correspondence, see (O.C., V/1).

5 The D'Alembert Research Group has already published several reports on its activities, and some of them underline the importance of such an edition of D'Alembert's complete work for the field of the Eighteenth Century Studies. See in particular (Chouillet, De Gandt and Passeron, 1998), (Paty, 2002), (Crépel, 2005; 2006b). It has also spearheaded several collections of scientific articles, most of which will be cited in this issue, namely (Michel and Paty, 2002), issue number 16 of the revue Dix-huitième siècle dedicated to D'Alembert, numbers 21, 38 and 40-41 of the revue Recherches sur Diderot et sur l'Encyclopédie. We also refer the reader to the special report published by P. Crépel (2009b) in Les génies de la science.

6 For a more detailed account of the research undertaken on D'Alembert's manuscripts, see (Ferret, Guilbaud and Passeron, 2012).

7 A part of his manuscripts, literary as well as scientific, apparently followed the same tumultous and complex trajectory as Condorcet's before finally reaching the safehouse of this library $(O . C$., $\mathrm{V} / 1$, pp. xx-xxiii). This collection of around 5300 folios is conserved at the Institute and classified under Ms. 1786 to Ms. 1793 and Ms. 2466 to 2473 . The Condorcet, Lagrange and Lacroix collections in this library also contain documents written by D'Alembert.

8 See (Passeron, 2005) and, more generally, on the question of D'Alembert's education and formative years, $\mathrm{n}^{\circ} 38$ of the revue Recherches sur Diderot et sur l'Encyclopédie (2005).

9 http://dalembert.academie-sciences.fr/Correspondance/.

10 The judgements of C. Truesdell against D'Alembert are not always a matter of a totally objective approach. For instance, he wrote that "at the age of twenty-four, there enters our scene now a talented but sinister personality who is to make in six years [from 1743] a sequence of brilliant discoveries but thereafter will write endlessly in what seems today no more than a dogged attempt to confine the capacities of mathematics and to belittle the solid work of others. This is D'Alembert". According to Truesdell, "after his essay on fluid motion, finished in 1749 [D'Alembert's Essai sur la résistance des fluides, published in 1752 but previously composed for the Berlin Academic's Prize of 1750] positive contributions to mechanics cease, except for one or two interesting details here and there in the voluminous polemic literature to which he devoted the rest of his scientific thought" (Truesdell, 1960a, p. 186). The historian doesn't specify which are these "one or two interesting details" and to consider the later scientific production with simple debates is obviously reducing. For some examples among others see (Grimberg, 1998) and (Guilbaud, 2007) for D'Alembert's contribution in hydrodynamics during and after the 1750's. From 1761, D'Alembert published most of its scientific works in its Opuscules mathematics; for an overview of the content of the nine volumes of the Opuscules (the ninth was unpublished), see (Crépel, 2006c, 2008) and O.C., III/1. 
11 See also (Badinter 1999, 2002, 2007).

12 http://dalembert.academie-sciences.fr/Correspondance/. For more information on this digital edition, see (Guilbaud, 2017).

13 It has been demonstrated that other strategies were deployed for other parts of his work, for example the publication of the second edition (1759) of his Mélanges de littérature, d'histoire et de philosophie, which followed on from the censorship of the Encyclopédie and his decision to step down as co-director of this work, and marked a new editorial policy for texts often linked to the Encyclopédie project. The reader could also consult the work by O. Ferret (2008) on D'Alembert's strategies in connection with the publication of the Eloges, drafted in the context of his role as permanent secretary of the French Academy.

14 The separation of his scientific contributions into two series (I et III) in the Euvres complètes is clearly designed to reflect these two distinct work phases.

15 See for example the case of this dispute with Euler and Daniel Bernoulli over the question of negative pressure $(O . C$. , vol. V/2, pp. cv-cxx).

16 See (Guilbaud, 2012; Schmit, 2015), and the critical edition in German of the Essai sur les élémens de philosophie (D'Alembert, 2017).

17 Among which, experimental physics (De Gandt 1996; Crépel 2006a), mechanics and dynamics (Firode, 1996, 2006; Schmit 2014, 2015), mathematical analysis (Gilain, 2010), mixed mathematics (Passeron 2006; 2009), music (Cernuschi, 1996).

18 For example, questions of rigidity and elasticity (Viard and Ismaël-Youssouf, 1996) and the problem of fluid resistance (Guilbaud, 2012).

19 Namely the entries AIR (Coste, 2009) and FigURE DE LA TERRE (Passeron, 1996).

20 Despite the quantity of studies and editions dedicated to this opening address, it is worth noting however that its scientific dimension has never been analysed. The critical edition of the text as part of volume IV/1 of the Euvres complètes, coordinated by J.-P. Schandeler, should redress this historiographical shortfall.

21 See http://enccre.academie-sciences.fr/. 